\title{
The Sustainable Development Goals and Agenda 2063: Implications for Economic Integration in Africa
}

\author{
Donald L Sparks ${ }^{1,2, *}$ \\ ${ }^{1}$ Professor of International Economics, The Citadel, USA \\ ${ }^{2}$ Professor of International Business, Management Center Innsbruck, Austria \\ *Correspondence: 191 Moultrie Street, Charleston, SC 29409, USA. Tel: 1- 843-953-5159. \\ E-mail: sparksd@citadel.edu \\ Received: October 22, 2016 Accepted: November 11, 2016 Published: December 4, 2016 \\ doi:10.5296/rae.v8i4.10194 URL: http://dx.doi.org/10.5296/rae.v8i4.10194
}

\begin{abstract}
This paper examines how Africa's recent efforts to promote economic integration, specifically the Regional Economic Communities (RECs) and the proposed Continental Free Trade Area (CFTA) are supported by and in harmony with the Post 2015 Development Agenda and the African Union's Agenda 2063 initiative.

The World Bank's Global Economic Prospects projects for the period 2014-2017 that five of the world's 13 top growing economies will be in Africa. However, it is distressing and puzzling that such growth has not been accompanied by reduced poverty, income inequality and unemployment. It is also unsettling that few states met all of the Millennium Development Goals (MDGs) which expired at the end of last year. Furthermore, Africa will likely be confronted by daunting challenges in the near term. This ominous situation is enhanced by the nature of Africa's trade, both within the continent and in the global economy.

To counter some of these constraints, especially the tariff barriers, the RECs and the CFTA will be critical in stimulating trade growth. Increased economic integration, either on a regional level or on a continent-wide level under the general guidelines of the Sustainable Development Goals (SDGs) and Agenda 2063 will result in increased trade which will, in the long term, increase incomes, reduce poverty, increase employment, provide greater consumer choice, and will offer shelter from exogenous external shocks. However, at least in the short term, such gains are also typically accompanied by loses. This paper calls for a continental Integration Compensation Funding Mechanism (ICFM) to balance some of these loses. The ICFM would be developed and managed by the African Development Bank, the United Nations Economic Commission for Africa and the African Union.
\end{abstract}

Keywords: Economic Development, Regional Economic Development, Regional Trade, African Union 


\section{Introduction}

Over the past decade Africa has seen unprecedented economic growth. For example, in 2013 the continent averaged GDP growth of $4 \%$, nearly double the global average. About $25 \%$ of the countries grew by $7 \%$ or more, and a few others were the fastest growing economies in the world. Indeed, the World Bank's Global Economic Prospects projects for the period 2014-2017 that five of the world's 13 top growing economies will be in Africa (Rwanda, Tanzania, Mozambique, Cote D'Ivoire, Democratic Republic of Congo, and the fastest projected is Ethiopia).

However, it is distressing and puzzling that such growth has not been accompanied by reduced poverty, income inequality and unemployment. It is also unsettling that few states met all of the Millennium Development Goals (MDGs) which expired at the end of last year. Furthermore, Africa will likely be confronted by daunting challenges in the near term. Perhaps most important will be slower growth in other emerging markets. As these emerging economies start to slow (especially the People's Republic of China), then the implications could be serious. For example, commodity demand and prices would fall. The reduction of some $50 \%$ of oil prices has worsened the terms of trade for not only oil producers, but the prices of 36 other commodities (including gas, gold, iron ore, coco, coffee and rubber) are closely correlated to the decreased price oil.

This ominous situation is enhanced by the nature of Africa's trade. Africa's trade openness has increased over the past 15 years, illustrated by its new partnerships with China and other emerging markets (China is now the most important single trading partner for sub-Saharan Africa). Indeed, average trade openness (for sub-Saharan Africa), measured as the total of imports and exports as a percentage of GDP, increased from $41 \%$ of GDP in the 1990 s to $45 \%$ in the 2000s. However, such openness makes the continent more vulnerable to external shocks. Moreover, Africa accounts for less than $5 \%$ of global trade, and until recently much of that trade was in extractive commodities with little local value added. For two-thirds of the countries in sub-Saharan Africa, the majority of their exports come from only one or two products. In a dozen countries in the region, one product constitutes $75 \%$ or more of total exports. For example, Angola's major export, oil, accounts for more than $90 \%$ of its total exports. Most of the region's export growth has been driven by natural resources, with petroleum, ores, base metals and gold accounting for $75 \%$ of the increase between 2000 and 2011. Primary products account for approximately $80 \%$ of the region's export revenues, about the same level as during the 1960s. Such dependence leaves the continent subject to fluctuations of global prices.

Africa remains the least integrated area of the world, with the average centrality about half of that of other emerging and developing markets. Trade between African states is low: in 2013 regional trade within Africa comprised around 12\% of the total (compared with ASEAN, where it is $30 \%$, North America, at $40 \%$ or Europe where regional trade equals $60 \%$ of total trade). In a few countries (ie, Lesotho and Swaziland) intra-regional trade comprises the majority of their total trade, but the vast majority of countries conduct only a small amount of trade with continental neighbors. However, it should be noted that the intra-regional trade of 
the three largest Regional Economic Communities (RECs) from 2004 to 2014 grew from \$30 billion to $\$ 102.6$ billion.

The demand for goods and services from nearby markets are low, sometimes described as the "non-complementary" problem: these countries generally have relatively few goods and services to trade with each other. Most African states produce similar exports, primary agricultural or mineral commodities, and, as most of the value added is carried out in Western industrialized countries, there is little African demand for these products. Indeed, despite regional proximity, Africa trades more with Europe, the US and China than with other African states. What trade that does exist is often in the informal sector, and consequently difficult to quantify. Their transport infrastructure (which is often inadequate in any event) is geared towards export to the EU, Japan and North America (and more recently towards China), rather than to neighbouring countries. It can cost more to ship an automobile next door than to import it from Europe. Also, as the landlocked countries' trade is principally with countries outside Africa, nearby countries are often viewed as competitive obstacles rather than potential markets. African states generally maintain high tariff barriers and are more than three times those of developed economies, at approximately $13 \%$ compared to under $4 \%$. Indeed, according to the IMF, just bringing average tariffs to the global average level could result in a $14 \%$ increase in trade.

In addition to these constraints, there are significant market size constraints (small economies which cannot capture scale economies nor generate sufficient demand for imported goods and services nor increased investment - foreign or domestic). Other serious impediments include currency inconvertibility, poor road and other transport infrastructure, border bottlenecks (wearisome customs checkpoints, graft, etc), lack of political will to cede even small amounts of political sovereignty, and low levels of productivity that make relatively expensive exports unattractive. Finally, the economic benefits for economic integration may take some time to become apparent, and these benefits may be widely and unevenly dispersed (witness the old East African Community in the 1970s where Kenya grew at the expense of Tanzania and Uganda, the other members). The costs, on the other hand, are often immediate and concentrated, resulting in social and political backlash.

To counter some of these constraints, especially in reducing the tariff barriers, the RECs and the proposed Continental Free Trade Area (CFTA) will be critical in stimulating trade growth. The evidence that increased trade, based on specialization and comparative advantage, can lead to general welfare is strong, certainly in the long term. Economists since Adam Smith and David Ricardo have made the compelling case that reducing trade restrictions results in significant welfare gains. Indeed, if Africa could increase its share of global trade by only one percent, that would result in an annual additional income of over US\$200 billion (equal to five times the amount of Official Development Assistance-ODA-- the continent receives). Such an increased income stream would go a long way in facilitating sustained economic growth and development in a region that is in much need of both.

However, at least in the short term, such gains are also typically accompanied by loses. This paper will examine how Africa's recent efforts in economic integration, specifically the 
Regional Economic Communities (RECs) and its proposed Continental Free Trade Area (CFTA), which are intended to (among other things) increase trade flows between members, are supported by the Post 2015 Development Agenda and the AU's Agenda 2063 initiative. In other words, are these economic integration initiatives in harmony with the Sustainable Development Goals and Agenda 2063, and what are economic consequences of such integration?

\section{The Post-2015 Development Agenda}

The post-2015 development agenda has made important steps in being inclusive. Drafting the MNGs were not as inclusive as many would have liked and in 2014 the African Union presented its Common African Position (CAP) on the Post Development Agenda. The CAP includes a more participatory approach that includes stakeholders at national, regional and continental levels in order to, "... help address the consultation gap in the initial preparation and formulation of the Millennium Development Goals." The agenda provides Africa with a unique consensus on common challenges, priorities and aspirations. It suggests that in order to strengthen partnerships for trade, "We must accelerate regional integration including by boosting intra-African trade and enhancing Africa's participation in the global supply chain systems". It also calls for implementing continental mechanisms to promote intra-African trade, including the NEPAD framework. In a 2015 report, the UNECA stated that, "in the formulating of the sustainable development goals, considerable effort was made to ensure that the proposed goals, targets and indicators were in alignment with the visions, principles, guiding framework and criteria set out at the global and regional level". In other words, the SDGs were actually drafted with Africa's regional and continental integration schemes in mind.

The overall post 2015 development agenda is to integrate social, economic, and environmental policies towards sustainable human development. Unlike the Millennium Development Goals which expire in 2015, the new, Sustainable Development Goals as well as the AU's Agenda 2063 were drafted in a collaborative manner, from the ground up, not from the top down. As such, the commitment to these goals are likely to be stronger and thus the chances of success greater.

Agenda 2063 is both a vision and an action plan. In their 50th Anniversary Solemn Declaration, the Heads of State and Government of the African Union (AU) acknowledged past successes and challenges, affirmed their commitment to the continent's accelerated development. Agenda 2063 created a vision and eight ideals to serve as pillars for the continent's development. It is hoped that Agenda 2063 will translate into concrete objectives, milestones, goals, targets and actions/measures. Agenda 2063 “... is a call for action to all segments of African society to work together to build a prosperous and united Africa based on shared values and a common destiny". Specifically, the Agenda calls for:

A more united and strong Africa. Africa today is more united, a global power to reckon with, capable of rallying support around a common agenda and speaking with one voice with demonstrated strong capacity to negotiate and withstand the influence of forces that would like 
to see it divided.

Strong and well-functioning regional institutions. Africa's sub regional institutions have been rationalized and the eight officially AU-recognized Regional Economic Communities (CEN-SAD, COMESA, EAC, ECCAS, ECOWAS, IGAD, SADC and UMA) are today strong development and political institutions that citizens' can count on and Agenda 2063 can stand on.

While there is debate about the current economic and political strengths of some of the RECs, this part of the agenda is no doubt intended to be aspirational. Clearly, closer economic integration is an essential part of the Agenda 2063's overall call to action. The agenda supports African Union's vision of “An Integrated, prosperous and peaceful Africa, driven by its own citizens and representing a dynamic force in the global arena".

The Sustainable Development Goals (SDGs), also known as the Global Goals are a set of seventeen targets relating to fostering international development. They ultimately aim to integrate social, economic, and environmental policies towards sustainable development. Thus, they two require significant regional economic integration for success, as will be discussed below.

The SDGs were first formally discussed at the United Nations Conference on Sustainable Development held in Rio de Janeiro in June 2012 (Rio+20). The Intergovernmental Negotiations on the Post-2015 Development Agenda (IGN) began in January 2015 and ended in August 2015. Following the negotiations, Transforming our World: the 2030 Agenda for Sustainable Development was adopted at the UN Sustainable Development Summit in September2015 in New York. The 17 SDGs include 169 targets to meet these goals (see Appendix I for the complete list of goals and targets) and 304 proposed indicators to show compliance.

\section{History of Economic Integration in Africa}

Regional economic integration initiatives have a long history in Africa, starting from the Southern African Customs Union (SACU), the world's oldest (established in 1910) and the original East African Community (EAC), which was in existence from 1967-1977. Since the era of independence in the 1960s there have been repeated calls for increased economic cooperation among African states. The first proponent was Kwame Nkrumah, the visionary president of Ghana. Increased integration was seen as imperative to address the neo-colonial relationships (including trade patterns) which had continued Africa's overreliance on primary commodity exports (as discussed above).

Indeed, closer economic integration was one motivation for establishing the Organization of African Unity (OAU) in 1963. The OAU made limited progress towards the goal of regional economic integration; in 1991, it adopted the Treaty Establishing the African Economic Community (AEC), also known as the Abuja Treaty, aimed at promoting continental unity through harmonized economic policies within the RECs. The Abuja Treaty was quickly 
adopted by the African Union (AU), which still believes that regional economic integration is key in driving economic development on the continent.

The RECS

The Regional Economic Communities (RECs) group together countries in sub-regions in order to achieve greater economic integration. They are styled as the "building blocks" of the African Union and are also central to implementing the New Partnership for Africa's Development (NEPAD) and Agenda 2063. The eight RECs, each established under a separate regional treaty, are:

- Arab Maghreb Union (UMA)

- Common Market for Eastern and Southern Africa (COMESA)

- Community of Sahel-Saharan States (CEN-SAD)

- East African Community (EAC)

- Economic Community of Central African States (ECCAS)

- Economic Community of West African States (ECOWAS)

- Intergovernmental Authority on Development (IGAD)

- Southern African Development Community (SADC)

Most observers agree that the eight RECs have varying degrees of success, with COMESA, ECA, ECOWAS and SADC being at the more successful range.

CFTA

In 2012 leaders at the AU Summit endorsed a plan to set up a Continental Free Trade Area (CFTA) by 2017 under the theme "boosting intra-African trade". The proposed CFTA would be a key component of the AU's strategy to lift trade within the region by at least 25-30 percent in the next decade. The "Declaration on boosting intra-African trade and the establishment of a continental free trade area" calls on member states, regional economic communities and development partners to adopt the necessary measures toward the effective implementation of an "Action Plan", ie, a document produced during the AU trade ministers' meeting in 2011 detailing priority action clusters to address obstacles to increasing intra-African trade.

Enhancing this trade - such as through a large continent-wide trade deal - and deepening market integration "can contribute significantly to sustainable economic growth, employment generation, poverty reduction, inflow of foreign direct investment, industrial development, and better integration of the continent into the global economy," the AU declaration said. The free trade area would not be a customs union as each member state will retain its rights to set its tariff regime (subject to WTO rules) with any other non-member.

Some observers believe establishing a CFTA by 2017 is overly-optimistic. For example, at a 2011 meeting of African leaders, South African President Jacob Zuma predicted at the time that this process would likely meet substantial challenges along the way, including the "uneven and unequal development" between countries and regions, along with infrastructure limitations. 
And former Nigerian President Goodluck Jonathan has maintained that the 2017 target date was unrealistic, saying, "There are no quick-fixes to integration,". Even if the pan-African deal does manage to finalize, there would be limited scope for deepened trade in the short term since there are many other issues that would still need to be addressed (as discussed above).

However, the recent success with combining three existing free trade areas into a 26-nation "Tripartite FTA," may make a larger grouping more feasible, but perhaps with a longer time line. The Tripartite FTA, when finalized, will encompass three existing regional economic communities, the Common Market for Eastern and Southern Africa (COMESA), the East African Community (EAC), and the Southern Africa Development Community (SADC) -- 26 countries in total representing $57 \%$ of the continent's population and $58 \%$ of continental GDP.

The decade and a half post-independence period resulted in relatively good economic performance, but in the late 1970s and 1980s the continent suffered a drastic stagnation. This period has been characterized as the "lost decade for Africa", with an average annual decline of per capita income of about 1.7 per cent. It was during this period that the "Monrovia Symposium on the future development prospects of Africa towards the year 2000"was convened in 1979 in Monrovia, Liberia. The Symposium produced the "Monrovia Declaration of Commitment of Heads of State and Government of the Organization of African Unity on Guidelines and Measures for National and Collective Self-Reliance in Social and Economic Development for the Establishment of a New International Order." The declaration was adopted by the OAU as "The Monrovia Strategy". The OAU Summit then met in 1980 at a special session in Lagos, Nigeria, to prepare and adopt the "Lagos Plan of Action for the economic development of Africa; 1980-2000" (LPA).

The LPA has been characterized as a response by African states to the World Bank's 1981 Berg report. The plan suggested that Africa's economic crisis was at least in part due to the Structural Adjustment Programs (SAPs) of the World Bank and International Monetary Fund (commonly known as the "Washington Consensus") and the vulnerability of African economies to worldwide economic shocks, such as the 1973 oil crisis. The plan was meant to implement the Monrovia Strategy and covers most development sectors (food and agriculture, industry, natural resources, human resources development and utilization, transport and communications, trade and finance, energy etc.). The AU adopted the Final Act of Lagos as an annex of LPA, specifically calling for the establishment of "an African Economic Community, so as to ensure the economic, social and cultural integration of the continent".

By 2015 the number and complexity of overlapping regional organizations are astounding. Unfortunately, the Abuja Treaty's legal framework failed to prevent multiple memberships. While the treaty provided for eight RECs in Africa's five sub-regions, there are currently dozens of other regional economic organizations, resulting in a host of problems, including duplication of effort and responsibilities and also for competition for resources. This "spaghetti-bowl" membership (see figure 1) complicates policy management, generally increases confusion between the AU, national governments and regional organizations, and results all too often in objectives which are uncoordinated or duplicated. Indeed, the IMF suggests that, "...their overlapping groupings greatly reduce their effectiveness." 


\section{MInstitute ${ }_{\text {Imk }}^{\text {Macrothink }}$}

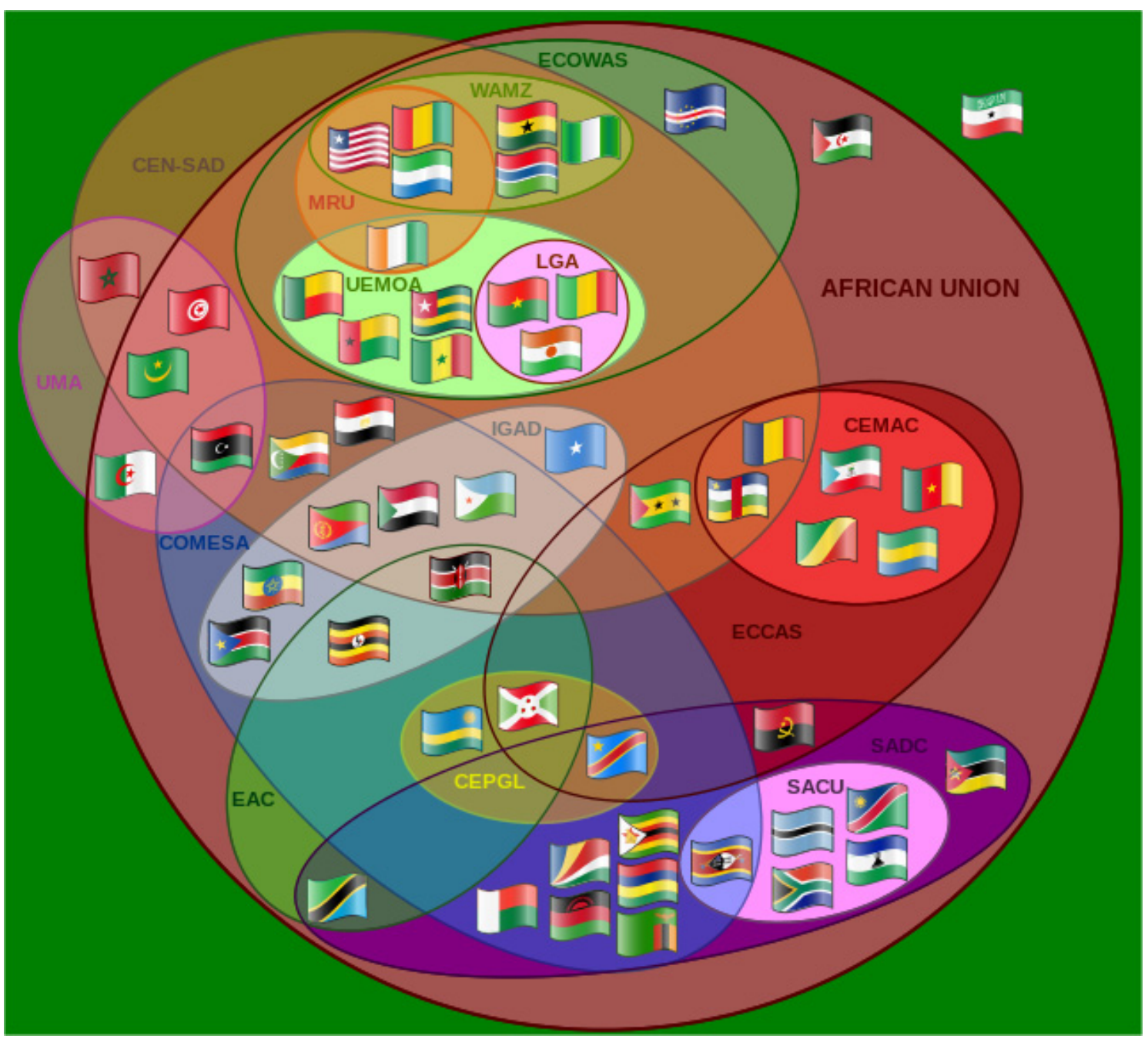

Figure 1. An Euler Diagram of Regional Economic Organizations in Africa

\section{Harmonizing the SDGs, Agenda 2063 with the RECs and the CFTA}

As discussed above, Africa's economic integration in general and the RECs and a CFTA in particular are fully supported by both the Sustainable Development Goals and the Agenda 2063. The following SDGs (see appendix for the complete listing) support such economic integration either directly or indirectly:

\section{Direct impacts:}

Goal 2: End hunger, achieve food security and improved nutrition and promote sustainable agriculture. Targets $2.1,2.2,2.3,2.4,2.6,2.7,2.8$

Goal 8: Promote inclusive and sustainable economic growth, employment and decent work for all. Targets $8.1,8.2,8.3,8.5,8.6,8.12$,

Goal 9: Build resilient infrastructure, promote sustainable industrialization and foster innovation. Targets 9.6, 9.7, 9.8 
Goal 10: Reduce inequality within and among countries. Targets 10.1, 10.2, 10.3, 10.6, 10.7, $10.9,10.10,10.11$

Goal 17: Revitalize the global partnership for sustainable development. Targets 17.6, 17.7, $17.8,17.9,17.10,17.11,17.12,17.13,17.14,17.15,17.16,17.18,17.19$

\section{Indirect impacts:}

Goal 1: End poverty in all its forms everywhere. Targets 1.1, 1.2, 1.6, 1.7

Goal 7: Ensure access to affordable, reliable, sustainable and modern energy for all. Target 7.1

Goal 11: Make cities inclusive, safe, resilient and sustainable. Targets 11.9, 11.10

Goal 15: Sustainably manage forests, combat desertification, halt and reverse land degradation, halt biodiversity loss. Targets 15.4, 15.5, 15.6, 15.7, 15.8, 15.9, 15.10, 15.11, 15.12

Goal 16: Promote just, peaceful and inclusive societies. Targets 16.4, 16.5, 16.7

As mentioned earlier, the majority of economists reason that increased economic integration (especially increased trade) among states will lead to a positive sum game, and an increase in the continent's income and growth potential. Indeed, according to the IMF, “...increased trade has had a significant and positive influence on growth...". Of the $1.4 \%$ increase in GDP annual growth between1990-2000, the increase in trade openness is estimated to have contributed $0.6 \%$. These dynamic effects of increased economic integration can be the result of increased competition and resulting efficiencies, scale economies, increased foreign direct investment (FDI) and in general a better utilization of resources.

Nonetheless there are three short term downsides to closer integration (originally identified by Viner 1950): trade creation, trade diversion and loss from tariff revenues. Trade creation can occur after economic integration when production (either by the original country or from a country now in the trade bloc) is now more competitive in the larger market bloc and exports increase within the new group. This may benefit the original country, but it could also create trade in a competing nation. Thus, the result may not be Pareto Optimum, as generally there will be losers as well as winners, certainly in the short term. The most serious negative consequence of increased integration would be trade diversion. This occurs within a trade bloc (assuming high tariffs against non-members), as imports from non-members are discouraged and substituted by existing members' production. As the trade bloc expands to other new members, those new members may be lower cost producers. With no barriers the lower cost goods and services will now compete with domestic production. Such competition would lead to lower prices for consumers, but could result (at least in the short term) with higher domestic unemployment. As increasing employment and incomes are both explicit SDGs, such a result would suggest that increased trade may well not be in harmony in the short term.

Of course, regional trade should increase incomes and thus access to food. Trade should also bring down prices and reduce food scarcity. However, some new members would likely be more efficient in agriculture and the domestic agricultural sector could be damaged. As agricultural production is also explicitly listed as a SDG increased trade in agricultural 
products may not be in harmony, at least in the short term. The same can be said of industry, as there is the real fear of loss of industry due to monopolization.

The other major negative of increased integration, certainly that of eliminated tariff barriers, would be the loss of tariff revenue to member states. Developed economies do not depend on tariff revenue for a significant share of their total annual budgets. Indeed, for the OECD members the amount of tariffs as a percent of total budgetary revenue averages $2 \%$. This is because these countries have a range of revenue sources, including particularly personal and corporate taxes and value added taxes (VATs). For African countries, however, tariff revenues are much more important as personal and corporate incomes are generally quite low. In other words, many of these countries depend on tariff revenues to fund their budgets. For example, the Namibia, Botswana, Lesotho, Swaziland (NBLS) members of the Southern African Customs Union (SACU) receive on average about half of their government budgetary revenues from the compensatory formula that shares the total custom revenues in the union (for historical and political reasons, South Africa does not receive compensatory revenue).

As previously noted that since intra-African trade is low (perhaps $10 \%$ of total trade), the loss of tariff revenues would not be great in absolute terms. However, as virtually every African government is "cash strapped", any loss of revenue, without a compensatory balance, would be felt. Also, according to a study done by Professor Kowalski, many developing countries' tariff schedules are characterized by high tariff rates in low import demand elasticity sectors and a prevalence of high tariff rates in high import demand elasticity sectors. Such a structure of tariff rates could lessen any negative revenue impacts of tariff reduction (compared to a situation where high rates are applied on low elasticity products). Nonetheless, as SDG target 1.7 calls for increased government resources for pro-poor development strategies, this could be viewed as a negative result.

In addition, removing trade barriers means that countries lose a degree of sovereignty. For example, most African states currently ban the use of genetically modified (GM) foods, including inputs such as seeds. However, counties that want to keep GM inputs our may find themselves in violation of a free trade regime. As reducing health risks is SGD 13.3, such loss of sovereignty may not be in harmony with the post 2015 agenda. Along those lines, many people fear loss of culture. A free trade regime might require the "McSouthafricanization" of the domestic food and consumer products industry.

\section{Conclusions and Recommendations}

This paper has maintained that Africa's regional economic integration efforts, and particularly the Regional Economic Communities and the Continental Free Trade Agreement generally are in harmony with the Sustainable Development Goals and the Agenda 2063. Indeed, such integration is essential in meeting those lofty goals.

Nonetheless, as shown above, there can be downsides. Trade diversion, loss of tariff revenues, loss of sovereignty and unintended, negative cultural ramifications are all important considerations. However, with sufficient political will these negative aspects can be 
ameliorated. For example, the European Union tries to assist its members' agricultural sectors with its Common Agriculture Program (CAP - not to be confused with the African Common Position on the Post-2015 Development Agenda). This EU's CAP is a system of agricultural subsidies and other programs, introduced in 1962 and has undergone several changes since then.

To balance some of these loses in Africa this paper calls for a continental Integration Compensation Funding Mechanism (ICFM)(Note 1). The ICFM would be developed and managed by the African Development Bank, the United Nations Economic Commission for Africa and the African Union. It would be chaired on an annual rotating basis by the chief operating officer of the above mentioned organizations and would have a small secretariat housed at the AUC. This fund would collect revenues from the members' external tariff regimes on non-African trade partners and distributed on a formula based on gains and losses (perhaps using the SACU mechanism as a model, see Flatters, F., and M. Stern 2006 and Senatla, et al 2010).

It outside the scope of this paper to look at each country and examine the costs and benefits of a continental free trade area.(Note 2) Perhaps such an analysis can be undertaken as part of the planning process, and thus this paper serves as a call for such a study. There are several analytical models to help calculate such costs and benefits: the Global Trade Analysis Project model, the Trade Complementary Index, the Trade Intensity Index and the World Integrated Trade Solution (Software for Market Analysis and restrictions on Trade WITS-SMART). Finally, the Millennium Institute Threshold 21 development model uses system dynamics modelling tools and other analytic techniques to analyse the interconnectedness between economic, social, and environmental factors, and issues of sustainability.

Africa's share of foreign value added embedded in the production of exports is lower than other regions (although a few countries --Ethiopia, Kenya, Seychelles, South Africa and Tanzania-have seen their share of foreign value added increase by $5 \%$ over the past two decades). More troubling, the depth of such integration has not increased measurably since the 1990s, unlike most other regions of the world. The continent has yet to take advantage of joining global value chains. Nonetheless, Africa has an amazing opportunity to better exploit its comparative advantage in trade, especially in joining value chains in areas such as agro-business, light manufacturing and textiles. Global value chains have allowed emerging markets to enter the chain without having to provide all the upstream capabilities (what Japan, China and Easter Europe have been so successful in doing).

In sum, Africa still trades below its potential, both in its position in global value chains and in total trade flows. Increased integration, either on a regional level or on a continent-wide level under the general guidelines of the SDGs and Agenda 2063 will result in increased trade which will, in the long run, increase incomes, reduce poverty, increase employment, provide greater consumer choice, and will offer shelter from exogenous external shocks. Such economic integration efforts should be embraced by Africa and the international community. 


\section{Acknowledgements}

The author would like to acknowledge the invaluable assistance of: David Luke, Chief, Africa Trade Center, Economic Commission for Africa, Addis Ababa, Firma Estiphanos, PhD, Department of Economics, University of Addis Ababa, Meredith Metzler, Economic Officer, US Mission to the African Union, Addis Ababa, David Konkel, Director, Office of Economic Analysis, US Department of State, Washington, DC, and Kaisa Kimmel, Inclusive Growth and Sustainable Development Cluster, UNDP, Addis Ababa. Grateful thanks also to the Fulbright Program which supported this consultancy where I served as a Visiting Fulbright Specialist (Economics) at the African Union Commission. The conclusions are of course those of the author.

\section{References}

"United Nations System Task Team on the Post-2015 United Nations Development Agenda. Realizing the Future We Want for All: Report to the Secretary-General”. New York, UN 2012.

Abraham, K. (2008). The Challenges of Accelerating Economic and Political Integration in the Formation of a Union Government. In Murithi, T. (ed.), Towards a Union Government for Africa: Challenges and Opportunities. Pretoria: Institute for Security Studies.29-43.

African Development Bank (2010). Africa in 50 Years' Time - The Road towards Inclusive Growth. Tunis: African Development Bank.

African Development Bank (2014). African Development Report 2014: Regional Integration for Inclusive Growth. AfDB.

African Union (2011). Africa Consensus Statement to Rio+20. Africa Regional Preparatory Conference for the United Nations Conference on Sustainable Development (Rio+20), Addis Ababa, Ethiopia.

African Union (2014). Common African Position (CAP) on the Post 2015 Development Agenda. Addis Ababa: AU.

African Union Commission, Economic Commission for Africa, African Development Bank and United Nations Development Programme (2012). Post-2015 Development Agenda: Emerging Consensus from Africa - Outcome Document. Addis Ababa, Ethiopia.

Akokpari, J. (2008). Dilemmas of Regional Integration and Development in Africa. In Akokpari, J., Ndinga-Muvumba, A. And Murithi, T. (eds.), The African Union and its Institutions. Johannesburg: Jacana Media. 85-113.

Arndt, C., \& Tarp, F. (2007). Trade Policy Reform and the Missing Revenue. Journal of African Economies, number 17.

Bello, A. (2004). Food Security, Agricultural Efficiency and Regional Integration. University of Philippines Working Paper. 
Bolaji-Adio, Adedayo (2015). The Challenge of Measuring SDG 16: What Role for African Regional Frameworks? ECDPM Discussion Paper 175.

Chandra, Alexander C. (2009). The Pursuit of Sustainable Development Through Regional Economic Integration. Institute for Sustainable Development.

Clausing, Kimberly (2001). Trade Creation and Trade Diversion in the Canada-United States Free Trade Agreement. Canadian Journal of Economics, 34(3), 677-696. https://doi.org/10.1111/0008-4085.00094

Dawes Sharon S. (2015). Policy Framework and Institutional Arrangements. Center for Technology in Government.

Department of International Development (2013). “Can Trade Improve Food Security?”, Trade and Investment Analytical Paper Number 9.

Ebrill, L., Stotsjy, J., \& Gropp, R. (1999). Revenue Implications of Trade Liberalisation. International Monetary Fund, Washington DC.

Edozie, Rita Kiki \& Gottschalk, Keith. (2014). The African Union's Africa: New Pan-African Initiatives in Global Governance. Michigan State University Press.

Eicher, T., Henn, C., \& Papageorgiou, C (2008). Trade Creation and Diversion revisited: Accounting for Model Uncertainty and Natural Trading Partner Effects. IMF Working Paper, WP/08/66. https://doi.org/10.2139/ssrn.1609675

Estiphanos, G., \& Yifredew, S. (2010). Enhancing Intra Regional Trade for Integration: The Case for Intra African Trade. NETRIS Seminar, University of KwaZulu Natal, Durbam, South Africa, 2010.

Flatters, F., \& M. Stern. (2006). SACU Revenue Sharing: Issues and Options. Policy Brief Washington, DC: USAID/SEGA.

Frankel, Jeffrey. (1997). Regional Trading Blocs in the World Economic System. Washington, DC: Institute for International Economics. https://doi.org/10.7208/chicago/9780226260228.001.0001

Gaomab, Mihe \& Paul Hartman. (2006). The economics of the 2002 SACU Agreement. Journal of Law and Economics in International Trade.

Griggs, David, et al. (2014). An Integrated Framework for Sustainable Development Goals. Ecology and Society, 19(4), 49. https://doi.org/10.5751/ES-07082-190449

Grynberg Roman \& Motswapong Masedi. SACU Revenue Sharing Formula: The History of An Equation.

International Monetary Fund (2015). Regional Economic Outlook: Sub-Saharan Africa. Washington, DC: IMF.

Jensen H G., \& Sandrey, R (2011). The Tripartite Free Trade Agreement: A Computer Analysis of the Impacts. In Stanley, R, Jensen, H G, Vink, V and Viljoen, W, (eds.), Cape 
to Cairo: An Assessment of the Tripartiate Free Trade Area. Stellenbosch: Trade Law Centre for Southern Africa.

Khandelwal, P. (2005). COMESA and SADC: Prospects and Challenges for Regional Trade Integration. UNU-CRIS Occasional Paper.

Khattry, B., \& Rao, J. M (2002). Fiscal Faux Pas? An Analysis of the Revenue Implications of Trade Liberalisation. World Development, 30(8), 1431-1444. https://doi.org/10.1016/S0305-750X(02)00043-8

Knebel, Christian \& Peters, Ralf. (2015). Direct and Indirect Linkages Between Non-Tariff Measures and the SDGs. LSE Africa Initiative.

Kowalski, Przemyslaw (nd). "Impact of Changes in Tariffs on Developing Countries" Government Revenues”. Purdue University Working Paper Series.

Krishna, Pravin (2003). Are Regional Trading Partners 'Natural'? Journal of Political Economy, 111(1). https://doi.org/10.1086/344802

Krueger, A O. (1999). Are Preferential Trade Arrangements Trade Liberalizing or Protectionist? Journal of Economic Perspectives, 13(4), 105-124. https://doi.org/10.1257/jep.13.4.105

Krueger, Anne (1999). Trade Creation and Trade Diversion under NAFTA. NBER Working Paper \#7429. National Bureau of Economic Research. https://doi.org/10.3386/w7429

Lawan, Sarah (2015). An African Take on the Sustainable Development Goals. Brookings Africa In Focus, October 13.

LeBlanc, David (2015). Toward Integration at Last? The Sustainable Development Goals as a Network of Targets. DESA Working Paper No. 141.

Longo, R., \& Sekkat, K. (2004). Economic Obstacles to Expanding Intra-African Trade. World Development, 32(8), 309-1321. https://doi.org/10.1016/j.worlddev.2004.02.006

Makochekanwa, Albert (2014a). The Potential Impact of a COMESA-EAC-SAC Tripartite FTA on Food Security. African Integration and Development Review, 7(2).

Makochekanwa, Albert (2014b). COMESA-EAC-SAC Tripartite FTA: Implications on Welfare and Food Security. African Integration and Development Review, 7(1).

Moutis, T. (2001). Why Do Poor Democracies Collect a Lot of Tariff Revenue? Economics and Politics, 13(1), 95-112. https://doi.org/10.1111/1468-0343.00085

Mwanza, William (2015). The New UN Sustainable development Goals and regional Integration in Africa. Tralac Trade Law Centre.

Ncube, Mthuli, Brixiova, Zuzana \& Meng, Qingwei (2015). Can Intra-African Trade Act as a Global Shock Absorber in Africa?. LSE Africa Initiative.

Osiemo, Francis (2015). Balancing Sustainability Goals and Economic Integration in the EAC. Sustainable Development, 4(6). 
Renwick, Danielle (2015). Sustainable Development Goals”. Council on Foreign Relations, CFR Backgrounders, September.

Rosson, C., Parr, C., Ford Runge \& Kirby S. Moulton. (2000). Preferential Trading Arrangements: Gainers and Losers. In Phillip King, (ed.), International Economics and International Economic Policy: A Reader $3^{\text {rd }}$ edition. Boston: McGrawHill.

Saurombe, A. (2012). An Analysis of Economic Integration in Africa with Specific Reference to the African Union and the African Economic Community. South African Journal of Public Law, 27, 292-314.

Senatla, Lesedi, Tayani Chankuluba, and Chepete SG Chepete (2010). The Southern African Customs Union (SACU) Agreement: Past, Present and Future Prospects. Research Department, Bank of Botswana.

Sezibera, Richard (2015). Regional Integration and Sustainable Development in the East African Community. Berlin: Stiftung Wissenschaft und Politik.

Sparks, Donald L. (2015). Economic Trends in Africa South of the Sahara", in Africa South of the Sahara 2016 (44 ${ }^{\text {th }}$ Edition).London: Routledge, Taylor and Francis Group.

Tavares, R., \& Tang, Vanessa. (2011). Regional Economic Integration in Africa: Impediments to Progress. South African Journal of International Affairs, 18(2), 217-233. https://doi.org/10.1080/10220461.2011.588826

Transforming our World: the 2030 Agenda for Sustainable Development

UNECA (2015a). Africa Regional Report on the Sustainable Development Goals: Summary. UNECA.

UNECA (2015b). "Progress report on the Implementation of Regional and International Agendas and Other Special Initiatives in the Sub-region". E/ECA/SA/ICE.XXXI/20/2015/7, February 2015.

Viner, Jacob (1950). The Customs Union Issue. New York: Carnegie Endowment for International Peace.

Weltz, M. (2014). A 'Culture of Conservatism:' How and Why African Union Member States Obstruct the Deepening of Integration. Strategic Review for Southern Africa, 36(1), 4-24.

Wonnacott,Paul, \& Mark Lutz (1989). Is There a Case for Free Trade Agreements? In Schott, J., (ed.), Free Trade Areas and U.S. Trade Policy. Washington, DC: Institute for International Economics.

World Bank (2015). Global Economic Prospects: The Global Economy in Transition. Washington, DC: IBRD.

\section{Notes}




\section{Macrothink}

Note 1. This would not be related in any way to the African Integration Fund whose purpose is to assist members of RECs in financing the "Minimum Integration Programme".

Note 2. For a comprehensive examination of the T-FTA's impact on welfare and food security, see Makochekanwa 2014a and 2014b.

\section{Appendix}

\section{The Sustainable Development Goals}

\section{Goal 1: End poverty in all its forms everywhere}

Targets

- $\quad 1.1$ By 2030, eradicate extreme poverty for all people everywhere, currently measured as people living on less than $\$ 1.25$ a day 1.2

- 1.2 By 2030, reduce at least by half the proportion of men, women and children of all ages living in poverty in all its dimensions according to national definitions

- 1.3 Implement nationally appropriate social protection systems and measures for all, including floors, and by 2030 achieve substantial coverage of the poor and the vulnerable

- $\quad 1.4$ By 2030, ensure that all men and women, in particular the poor and the vulnerable, have equal rights to economic resources, as well as access to basic services, ownership and control over land and other forms of 13 property, inheritance, natural resources, appropriate new technology and financial services, including microfinance

- $\quad 1.5$ By 2030, build the resilience of the poor and those in vulnerable situations and reduce their exposure and vulnerability to climate-related extreme events and other economic, social and environmental shocks and disasters

- 1.6 Ensure significant mobilization of resources from a variety of sources, including through enhanced development cooperation, in order to provide adequate and predictable means for developing countries, in particular least developed countries, to implement programmes and policies to end poverty in all its dimensions

- 1.7Create sound policy frameworks at the national, regional and international levels, based on pro-poor and gender-sensitive development strategies, to support accelerated investment in poverty eradication actions

\section{Goal 2: End hunger, achieve food security and improved nutrition and promote sustainable agriculture}

Targets

- 2.1 By 2030, end hunger and ensure access by all people, in particular the poor and people in vulnerable situations, including infants, to safe, nutritious and sufficient food all year round 
- $\quad 2.2$ By 2030, end all forms of malnutrition, including achieving, by 2025, the internationally agreed targets on stunting and wasting in children under 5 years of age, and address the nutritional needs of adolescent girls, pregnant and lactating women and older persons

- 2.3 By 2030, double the agricultural productivity and incomes of small-scale food producers, in particular women, indigenous peoples, family farmers, pastoralists and fishers, including through secure and equal access to land, other productive resources and inputs, knowledge, financial services, markets and opportunities for value addition and non-farm employment

- $\quad 2.4$ By 2030, ensure sustainable food production systems and implement resilient agricultural practices that increase productivity and production, that help maintain ecosystems, that strengthen capacity for adaptation to climate change, extreme weather, drought, flooding and other disasters and that progressively improve land and soil quality

- 2.5 By 2020, maintain the genetic diversity of seeds, cultivated plants and farmed and domesticated animals and their related wild species, including through soundly managed and diversified seed and plant banks at the national, regional and international levels, and promote access to and fair and equitable sharing of benefits arising from the utilization of genetic resources and associated traditional knowledge, as internationally agreed

- 2.6 Increase investment, including through enhanced international cooperation, in rural infrastructure, agricultural research and extension services, technology development and plant and livestock gene banks in order to enhance agricultural productive capacity in developing countries, in particular least developed countries

- $\quad 2.7$ Correct and prevent trade restrictions and distortions in world agricultural markets, including through the parallel elimination of all forms of agricultural export subsidies and all export measures with equivalent effect, in accordance with the mandate of the Doha Development Round

- $\quad 2.8$ Adopt measures to ensure the proper functioning of food commodity markets and their derivatives and facilitate timely access to market information, including on food reserves, in order to help limit extreme food price volatility

\section{Goal 3: Ensure healthy lives and promote well-being for all at all ages}

Targets

- $\quad 3.1$ By 2030 , reduce the global maternal mortality ratio to less than 70 per 100,000 live births

- $\quad 3.2$ By 2030, end preventable deaths of newborns and children under 5 years of age, with all countries aiming to reduce neonatal mortality to at least as low as 12 per 1,000 live births and under-5 mortality to at least as low as 25 per 1,000 live births

- $\quad 3.3$ By 2030, end the epidemics of AIDS, tuberculosis, malaria and neglected tropical diseases and combat hepatitis, water-borne diseases and other communicable diseases

- $\quad 3.4$ By 2030, reduce by one third premature mortality from non-communicable diseases through prevention and treatment and promote mental health and well-being 
- $\quad 3.5$ Strengthen the prevention and treatment of substance abuse, including narcotic drug abuse and harmful use of alcohol

- $\quad 3.6$ By 2020, halve the number of global deaths and injuries from road traffic accidents

- $\quad 3.7$ By 2030, ensure universal access to sexual and reproductive health-care services, including for family planning, information and education, and the integration of reproductive health into national strategies and programmes

- $\quad 3.8$ Achieve universal health coverage, including financial risk protection, access to quality essential health-care services and access to safe, effective, quality and affordable essential medicines and vaccines for all

- $\quad 3.9$ By 2030, substantially reduce the number of deaths and illnesses from hazardous chemicals and air, water and soil pollution and contamination

- $\quad 3.10$ Strengthen the implementation of the World Health Organization Framework Convention on Tobacco Control in all countries, as appropriate

- $\quad 3.11$ Support the research and development of vaccines and medicines for the communicable and noncommunicable diseases that primarily affect developing countries, provide access to affordable essential medicines and vaccines, in accordance with the Doha Declaration on the TRIPS Agreement and Public Health, which affirms the right of developing countries to use to the full the provisions in the Agreement on Trade Related Aspects of Intellectual Property Rights regarding flexibilities to protect public health, and, in particular, provide access to medicines for all

- $\quad 3.12$ Substantially increase health financing and the recruitment, development, training and retention of the health workforce in developing countries, especially in least developed countries and small island developing States

- $\quad 3.13$ Strengthen the capacity of all countries, in particular developing countries, for early warning, risk reduction and management of national and global health risks

\section{Goal 4: Ensure inclusive and quality education for all and promote lifelong learning}

- 4.1 By 2030, ensure that all girls and boys complete free, equitable and quality primary and secondary education leading to relevant and Goal-4 effective learning outcomes

- 4.2 By 2030, ensure that all girls and boys have access to quality early childhood development, care and preprimary education so that they are ready for primary education

- $\quad 4.3$ By 2030, ensure equal access for all women and men to affordable and quality technical, vocational and tertiary education, including university

- 4.4 By 2030, substantially increase the number of youth and adults who have relevant skills, including technical and vocational skills, for employment, decent jobs and entrepreneurship 
- 4.5 By 2030, eliminate gender disparities in education and ensure equal access to all levels of education and vocational training for the vulnerable, including persons with disabilities, indigenous peoples and children in vulnerable situations

- 4.6 By 2030, ensure that all youth and a substantial proportion of adults, both men and women, achieve literacy and numeracy

- $\quad 4.7$ By 2030, ensure that all learners acquire the knowledge and skills needed to promote sustainable development, including, among others, through education for sustainable development and sustainable lifestyles, human rights, gender equality, promotion of a culture of peace and non-violence, global citizenship and appreciation of cultural diversity and of culture's contribution to sustainable development

- $\quad 4.8$ Build and upgrade education facilities that are child, disability and gender sensitive and provide safe, nonviolent, inclusive and effective learning environments for all

- 4.9 By 2020, substantially expand globally the number of scholarships available to developing countries, in particular least developed countries, small island developing States and African countries, for enrolment in higher education, including vocational training and information and communications technology, technical, engineering and scientific programmes, in developed countries and other developing countries

- 4.10 By 2030, substantially increase the supply of qualified teachers, including through international cooperation for teacher training in developing countries, especially least developed countries and small island developing states

\section{Goal 5: Achieve gender equality and empower all women and girls}

Targets

- $\quad$ 5.1 End all forms of discrimination against all women and girls everywhere

- $\quad 5.2$ Eliminate all forms of violence against all women and girls in the public and private spheres, including trafficking and sexual and other types of exploitation

- $\quad 5.3$ Eliminate all harmful practices, such as child, early and forced marriage and female genital mutilation

- 5.4 Recognize and value unpaid care and domestic work through the provision of public services, infrastructure and social protection policies and the promotion of shared responsibility within the household and the family as nationally appropriate

- $\quad 5.5$ Ensure women's full and effective participation and equal opportunities for leadership at all levels of decisionmaking in political, economic and public life

- 5.6 Ensure universal access to sexual and reproductive health and reproductive rights as agreed in accordance with the Programme of Action of the International Conference on Population and Development and the Beijing Platform for Action and the outcome documents of their review conferences 
- $\quad 5.7$ Undertake reforms to give women equal rights to economic resources, as well as access to ownership and control over land and other forms of property, financial services, inheritance and natural resources, in accordance with national laws

- $\quad 5.8$ Enhance the use of enabling technology, in particular information and communications technology, to promote the empowerment of women

- $\quad 5.9$ Adopt and strengthen sound policies and enforceable legislation for the promotion of gender equality and the empowerment of all women and girls at all levels

\section{Goal 6: Ensure access to water and sanitation for all}

Targets

- $\quad$ 6.1 By 2030, achieve universal and equitable access to safe and affordable drinking water for all

- $\quad 6.2$ By 2030, achieve access to adequate and equitable sanitation and hygiene for all and end open defecation, paying special attention to the needs of women and girls and those in vulnerable situations

- $\quad 6.3$ By 2030, improve water quality by reducing pollution, eliminating dumping and minimizing release of hazardous chemicals and materials, halving the proportion of untreated wastewater and substantially increasing recycling and safe reuse globally

- 6.4 By 2030, substantially increase water-use efficiency across all sectors and ensure sustainable withdrawals and supply of freshwater to address water scarcity and substantially reduce the number of people suffering from water scarcity

- 6.5 By 2030, implement integrated water resources management at all levels, including through transboundary cooperation as appropriate

- $\quad$ 6.6 By 2020, protect and restore water-related ecosystems, including mountains, forests, wetlands, rivers, aquifers and lakes

- $\quad$ 6.7 By 2030, expand international cooperation and capacity-building support to developing countries in water- and sanitation-related activities and programmes, including water harvesting, desalination, water efficiency, wastewater treatment, recycling and reuse technologies

- $\quad 6.8$ Support and strengthen the participation of local communities in improving water and sanitation management

\section{Goal 7: Ensure access to affordable, reliable, sustainable and modern energy for all}

Targets

- $\quad$ 7.1 By 2030, ensure universal access to affordable, reliable and modern energy services

- $\quad 7.2$ By 2030, increase substantially the share of renewable energy in the global energy mix

- $\quad$ 7.3 By 2030, double the global rate of improvement in energy efficiency 
- 7.4 By 2030, enhance international cooperation to facilitate access to clean energy research and technology, including renewable energy, energy efficiency and advanced and cleaner fossil-fuel technology, and promote investment in energy infrastructure and clean energy technology

- $\quad$ 7.5 By 2030, expand infrastructure and upgrade technology for supplying modern and sustainable energy services for all in developing countries, in particular least developed countries, small island developing States, and land-locked developing countries, in accordance with their respective programmes of support

\section{Goal 8: Promote inclusive and sustainable economic growth, employment and decent work for all}

Targets

- 8.1 Sustain per capita economic growth in accordance with national circumstances and, in particular, at least 7 per cent gross domestic product growth per annum in the least developed countries

- 8.2 Achieve higher levels of economic productivity through diversification, technological upgrading and innovation, including through a focus on high-value added and labour-intensive sectors

- 8.3 Promote development-oriented policies that support productive activities, decent job creation, entrepreneurship, creativity and innovation, and encourage the formalization and growth of micro-, small- and medium-sized enterprises, including through access to financial services

- $\quad$ 8.4 Improve progressively, through 2030, global resource efficiency in consumption and production and endeavour to decouple economic growth from environmental degradation, in accordance with the 10-year framework of programmes on sustainable consumption and production, with developed countries taking the lead

- $\quad$ 8.5 By 2030, achieve full and productive employment and decent work for all women and men, including for young people and persons with disabilities, and equal pay for work of equal value

- $\quad$ 8.6 By 2020, substantially reduce the proportion of youth not in employment, education or training

- $\quad$ 8.7 Take immediate and effective measures to eradicate forced labour, end modern slavery and human trafficking and secure the prohibition and elimination of the worst forms of child labour, including recruitment and use of child soldiers, and by 2025 end child labour in all its forms

- $\quad$ 8.8 Protect labour rights and promote safe and secure working environments for all workers, including migrant workers, in particular women migrants, and those in precarious employment

- 8.9 By 2030, devise and implement policies to promote sustainable tourism that creates jobs and promotes local culture and products

- 8.10 Strengthen the capacity of domestic financial institutions to encourage and expand access to banking, insurance and financial services for all

- 8.11Increase Aid for Trade support for developing countries, in particular least developed countries, including through the Enhanced Integrated Framework for Trade-Related Technical Assistance to Least Developed Countries

- 8.12 By 2020, develop and operationalize a global strategy for youth employment and implement the Global Jobs Pact of the International Labour Organization 
Goal 9: Build resilient infrastructure, promote sustainable industrialization and foster innovation

Targets

- $\quad 9.1$ Develop quality, reliable, sustainable and resilient infrastructure, including regional and transborder infrastructure, to support economic development and human well-being, with a focus on affordable and equitable access for all

- $\quad 9.2$ Promote inclusive and sustainable industrialization and, by 2030, significantly raise industry's share of employment and gross domestic product, in line with national circumstances, and double its share in least developed countries

- 9.3 Increase the access of small-scale industrial and other enterprises, in particular in developing countries, to financial services, including affordable credit, and their integration into value chains and markets

- $\quad 9.4$ By 2030, upgrade infrastructure and retrofit industries to make them sustainable, with increased resource-use efficiency and greater adoption of clean and environmentally sound technologies and industrial processes, with all countries taking action in accordance with their respective capabilities

- 9.5 Enhance scientific research, upgrade the technological capabilities of industrial sectors in all countries, in particular developing countries, including, by 2030, encouraging innovation and substantially increasing the number of research and development workers per 1 million people and public and private research and development spending

- $\quad 9.6$ Facilitate sustainable and resilient infrastructure development in developing countries through enhanced financial, technological and technical support to African countries, least developed countries, landlocked developing countries and small island developing States 18

- 9.7 Support domestic technology development, research and innovation in developing countries, including by ensuring a conducive policy environment for, inter alia, industrial diversification and value addition to commodities

- $\quad 9.8$ Significantly increase access to information and communications technology and strive to provide universal and affordable access to the Internet in least developed countries by 2020

\section{Goal 10: Reduce inequality within and among countries}

Targets

- 10.1 By 2030, progressively achieve and sustain income growth of the bottom 40 per cent of the population at a rate higher than the national average

- $\quad 10.2$ By 2030, empower and promote the social, economic and political inclusion of all, irrespective of age, sex, disability, race, ethnicity, origin, religion or economic or other status

- 10.3 Ensure equal opportunity and reduce inequalities of outcome, including by eliminating discriminatory laws, policies and practices and promoting appropriate legislation, policies and action in this regard 
- $\quad$ 10.4 Adopt policies, especially fiscal, wage and social protection policies, and progressively achieve greater equality

- $\quad 10.5$ Improve the regulation and monitoring of global financial markets and institutions and strengthen the implementation of such regulations

- $\quad$ 10.6 Ensure enhanced representation and voice for developing countries in decision-making in global international economic and financial institutions in order to deliver more effective, credible, accountable and legitimate institutions

- $\quad$ 10.7 Facilitate orderly, safe, regular and responsible migration and mobility of people, including through the implementation of planned and well-managed migration policies

- $\quad 10.8$ Implement the principle of special and differential treatment for developing countries, in particular least developed countries, in accordance with World Trade Organization agreements

- $\quad 10.9$ Encourage official development assistance and financial flows, including foreign direct investment, to States where the need is greatest, in particular least developed countries, African countries, small island developing States and landlocked developing countries, in accordance with their national plans and programmes

- $\quad 10.10$ By 2030, reduce to less than 3 per cent the transaction costs of migrant remittances and eliminate remittance corridors with costs higher than 5 per cent

\section{Goal 11: Make cities inclusive, safe, resilient and sustainable}

Targets

- $\quad 11.1$ By 2030, ensure access for all to adequate, safe and affordable housing and basic services and upgrade slums

- $\quad 11.2$ By 2030, provide access to safe, affordable, accessible and sustainable transport systems for all, improving road safety, notably by expanding public transport, with special attention to the needs of those in vulnerable situations, women, children, persons with disabilities and older persons

- $\quad$ 11.3 By 2030, enhance inclusive and sustainable urbanization and capacity for participatory, integrated and sustainable human settlement planning and management in all countries

- 11.4 Strengthen efforts to protect and safeguard the world's cultural and natural heritage

- $\quad 11.5$ By 2030, significantly reduce the number of deaths and the number of people affected and substantially decrease the direct economic losses relative to global gross domestic product caused by disasters, including water-related disasters, with a focus on protecting the poor and people in vulnerable situations

- $\quad$ 11.6 By 2030, reduce the adverse per capita environmental impact of cities, including by paying special attention to air quality and municipal and other waste management

- $\quad 11.7$ By 2030, provide universal access to safe, inclusive and accessible, green and public spaces, in particular for women and children, older persons and persons with disabilities 
- $\quad$ 11.8 Support positive economic, social and environmental links between urban, peri-urban and rural areas by strengthening national and regional development planning

- 11.9 By 2020, substantially increase the number of cities and human settlements adopting and implementing integrated policies and plans towards inclusion, resource efficiency, mitigation and adaptation to climate change, resilience to disasters, and develop and implement, in line with the Sendai Framework for Disaster Risk Reduction 2015-2030, holistic disaster risk management at all levels

- 11.10 Support least developed countries, including through financial and technical assistance, in building sustainable and resilient buildings utilizing local materials

\section{Goal 12: Ensure sustainable consumption and production patterns}

Targets

- $\quad$ 12.1 Implement the 10-year framework of programmes on sustainable consumption and production, all countries taking action, with developed countries taking the lead, taking into account the development and capabilities of developing countries

- $\quad 12.2$ By 2030, achieve the sustainable management and efficient use of natural resources

- $\quad$ 12.3 By 2030, halve per capita global food waste at the retail and consumer levels and reduce food losses along production and supply chains, including post-harvest losses

- $\quad 12.4$ By 2020, achieve the environmentally sound management of chemicals and all wastes throughout their life cycle, in accordance with agreed international frameworks, and significantly reduce their release to air, water and soil in order to minimize their adverse impacts on human health and the environment

- $\quad 12.5$ By 2030, substantially reduce waste generation through prevention, reduction, recycling and reuse

- $\quad$ 12.6 Encourage companies, especially large and transnational companies, to adopt sustainable practices and to integrate sustainability information into their reporting cycle

- $\quad$ 12.7 Promote public procurement practices that are sustainable, in accordance with national policies and priorities

- $\quad 12.8$ By 2030, ensure that people everywhere have the relevant information and awareness for sustainable development and lifestyles in harmony with nature

- $\quad$ 12.9 Support developing countries to strengthen their scientific and technological capacity to move towards more sustainable patterns of consumption and production

- $\quad$ 12.10 Develop and implement tools to monitor sustainable development impacts for sustainable tourism that creates jobs and promotes local culture and products

- $\quad 12.11$ Rationalize inefficient fossil-fuel subsidies that encourage wasteful consumption by removing market distortions, in accordance with national circumstances, including by restructuring taxation and phasing out those harmful subsidies, where they exist, to reflect their environmental impacts, taking fully into account the specific needs and conditions of developing countries and minimizing the possible adverse impacts on their development in a manner that protects the poor and the affected communities 
Goal 13: Take urgent action to combat climate change and its impacts

Targets

- $\quad$ 13.1 Strengthen resilience and adaptive capacity to climate-related hazards and natural disasters in all countries

- $\quad$ 13.2 Integrate climate change measures into national policies, strategies and planning

- $\quad$ 13.2 Improve education, awareness-raising and human and institutional capacity on climate change mitigation, adaptation, impact reduction and early warning

- $\quad 13.4$ Implement the commitment undertaken by developed-country parties to the United Nations Framework Convention on Climate Change to a goal of mobilizing jointly $\$ 100$ billion annually by 2020 from all sources to address the needs of developing countries in the context of meaningful mitigation actions and transparency on implementation and fully operationalize the Green Climate Fund through its capitalization as soon as possible

- $\quad$ 13.5 Promote mechanisms for raising capacity for effective climate change-related planning and management in least developed countries and small island developing States, including focusing on women, youth and local and marginalized communities

\section{Goal 14: Conserve and sustainably use the oceans, seas and marine resources}

Targets

- $\quad 14.1$ By 2025, prevent and significantly reduce marine pollution of all kinds, in particular from land-based activities, including marine debris and nutrient pollution

- $\quad 14.2$ By 2020, sustainably manage and protect marine and coastal ecosystems to avoid significant adverse impacts, including by strengthening their resilience, and take action for their restoration in order to achieve healthy and productive oceans

- $\quad$ 14.3 Minimize and address the impacts of ocean acidification, including through enhanced scientific cooperation at all levels

- $\quad$ 14.4 By 2020, effectively regulate harvesting and end overfishing, illegal, unreported and unregulated fishing and destructive fishing practices and implement science-based management plans, in order to restore fish stocks in the shortest time feasible, at least to levels that can produce maximum sustainable yield as determined by their biological characteristics

- $\quad 14.5$ By 2020, conserve at least 10 per cent of coastal and marine areas, consistent with national and international law and based on the best available scientific information

- $\quad$ 14.6 By 2020, prohibit certain forms of fisheries subsidies which contribute to overcapacity and overfishing, eliminate subsidies that contribute to illegal, unreported and unregulated fishing and refrain from introducing new such subsidies, recognizing that appropriate and effective special and differential treatment for developing and least developed countries should be an integral part of the World Trade Organization fisheries subsidies negotiation 
- $\quad 14.7$ By 2030, increase the economic benefits to Small Island developing States and least developed countries from the sustainable use of marine resources, including through sustainable management of fisheries, aquaculture and tourism

- $\quad$ 14.8 Increase scientific knowledge, develop research capacity and transfer marine technology, taking into account the Intergovernmental Oceanographic Commission Criteria and Guidelines on the Transfer of Marine Technology, in order to improve ocean health and to enhance the contribution of marine biodiversity to the development of developing countries, in particular small island developing States and least developed countries

- $\quad$ 14.9 Provide access for small-scale artisanal fishers to marine resources and markets

- $\quad$ 14.10 Enhance the conservation and sustainable use of oceans and their resources by implementing international law as reflected in UNCLOS, which provides the legal framework for the conservation and sustainable use of oceans and their resources, as recalled in paragraph 158 of The Future We Want

Goal 15: Sustainably manage forests, combat desertification, halt and reverse land degradation, halt biodiversity loss

Targets

- $\quad$ 15.1 By 2020, ensure the conservation, restoration and sustainable use of terrestrial and inland freshwater ecosystems and their services, in particular forests, wetlands, mountains and drylands, in line with obligations under international agreements

- $\quad 15.2$ By 2020, promote the implementation of sustainable management of all types of forests, halt deforestation, restore degraded forests and substantially increase afforestation and reforestation globally

- $\quad 15.3$ By 2030, combat desertification, restore degraded land and soil, including land affected by desertification, drought and floods, and strive to achieve a land degradation-neutral world

- $\quad$ 15.4 By 2030, ensure the conservation of mountain ecosystems, including their biodiversity, in order to enhance their capacity to provide benefits that are essential for sustainable development

- $\quad$ 15.5 Take urgent and significant action to reduce the degradation of natural habitats, halt the loss of biodiversity and, by 2020 , protect and prevent the extinction of threatened species

- 15.6 Promote fair and equitable sharing of the benefits arising from the utilization of genetic resources and promote appropriate access to such resources, as internationally agreed

- $\quad$ 15.7 Take urgent action to end poaching and trafficking of protected species of flora and fauna and address both demand and supply of illegal wildlife products

- $\quad 15.8$ By 2020, introduce measures to prevent the introduction and significantly reduce the impact of invasive alien species on land and water ecosystems and control or eradicate the priority species

- $\quad$ 15.9 By 2020, integrate ecosystem and biodiversity values into national and local planning, development processes, poverty reduction strategies and accounts

- $\quad 15.10$ Mobilize and significantly increase financial resources from all sources to conserve and sustainably use biodiversity and ecosystems 
- $\quad$ 15.11 Mobilize significant resources from all sources and at all levels to finance sustainable forest management and provide adequate incentives to developing countries to advance such management, including for conservation and reforestation

- $\quad 15.12$ Enhance global support for efforts to combat poaching and trafficking of protected species, including by increasing the capacity of local communities to pursue sustainable livelihood opportunities

\section{Goal 16: Promote just, peaceful and inclusive societies}

Targets

- $\quad$ 16.1 Significantly reduce all forms of violence and related death rates everywhere

- 16.2 End abuse, exploitation, trafficking and all forms of violence against and torture of children

- $\quad$ 16.3 Promote the rule of law at the national and international levels and ensure equal access to justice for all

- $\quad$ 16.4 By 2030, significantly reduce illicit financial and arms flows, strengthen the recovery and return of stolen assets and combat all forms of organized crime

- $\quad$ 16.5 Substantially reduce corruption and bribery in all their forms

- 16.6 Develop effective, accountable and transparent institutions at all levels

- $\quad$ 16.7 Ensure responsive, inclusive, participatory and representative decision-making at all levels

- 16.8 Broaden and strengthen the participation of developing countries in the institutions of global governance

- $\quad$ 16.9 By 2030, provide legal identity for all, including birth registration

- $\quad$ 16.10 Ensure public access to information and protect fundamental freedoms, in accordance with national legislation and international agreements

- 16.11 Strengthen relevant national institutions, including through international cooperation, for building capacity at all levels, in particular in developing countries, to prevent violence and combat terrorism and crime

- $\quad$ 16.12 Promote and enforce non-discriminatory laws and policies for sustainable development

\section{Goal 17: Revitalize the global partnership for sustainable development}

Targets

\section{Finance}

- 17.1 Strengthen domestic resource mobilization, including through international support to developing countries, to improve domestic capacity for tax and other revenue collection

- $\quad 17.2$ Developed countries to implement fully their official development assistance commitments, including the commitment by many developed countries to achieve the target of 0.7 per cent of ODA/GNI to developing countries and 0.15 to 0.20 per cent of ODA/GNI to least developed countries 
ODA providers are encouraged to consider setting a target to provide at least 0.20 per cent of ODA/GNI to least developed countries

- 17.3 Mobilize additional financial resources for developing countries from multiple sources

- 17.4 Assist developing countries in attaining long-term debt sustainability through coordinated policies aimed at fostering debt financing, debt relief and debt restructuring, as appropriate, and address the external debt of highly indebted poor countries to reduce debt distress

- 17.5 Adopt and implement investment promotion regimes for least developed countries

\section{Technology}

- 17.6 Enhance North-South, South-South and triangular regional and international cooperation on and access to science, technology and innovation and enhance knowledge sharing on mutually agreed terms, including through improved coordination among existing mechanisms, in particular at the United Nations level, and through a global technology facilitation mechanism

- 17.7 Promote the development, transfer, dissemination and diffusion of environmentally sound technologies to developing countries on favourable terms, including on concessional and preferential terms, as mutually agreed

- $\quad$ 17.8 Fully operationalize the technology bank and science, technology and innovation capacity-building mechanism for least developed countries by 2017 and enhance the use of enabling technology, in particular information and communications technology

\section{Capacity building}

- 17.9 Enhance international support for implementing effective and targeted capacity-building in developing countries to support national plans to implement all the sustainable development goals, including through North-South, South-South and triangular cooperation

\section{Trade}

- 17.10 Promote a universal, rules-based, open, non-discriminatory and equitable multilateral trading system under the World Trade Organization, including through the conclusion of negotiations under its Doha Development Agenda

- 17.11 Significantly increase the exports of developing countries, in particular with a view to doubling the least developed countries' share of global exports by 2020

- $\quad 17.12$ Realize timely implementation of duty-free and quota-free market access on a lasting basis for all least developed countries, consistent with World Trade Organization decisions, including by ensuring that preferential rules of origin applicable to imports from least developed countries are transparent and simple, and contribute to facilitating market access

\section{Systemic issues}

Policy and institutional coherence 
- 17.13Enhance global macroeconomic stability, including through policy coordination and policy coherence

- 17.14 Enhance policy coherence for sustainable development

- $\quad$ 17.15 Respect each country’s policy space and leadership to establish and implement policies for poverty eradication and sustainable development

Multi-stakeholder partnerships

- 17.16 Enhance the global partnership for sustainable development, complemented by multi-stakeholder partnerships that mobilize and share knowledge, expertise, technology and financial resources, to support the achievement of the sustainable development goals in all countries, in particular developing countries

- 17.17Encourage and promote effective public, public-private and civil society partnerships, building on the experience and resourcing strategies of partnerships

Data, monitoring and accountability

- $\quad$ 17.18 By 2020, enhance capacity-building support to developing countries, including for least developed countries and small island developing States, to increase significantly the availability of high-quality, timely and reliable data disaggregated by income, gender, age, race, ethnicity, migratory status, disability, geographic location and other characteristics relevant in national contexts

- 17.19 By 2030, build on existing initiatives to develop measurements of progress on sustainable development that complement gross domestic product, and support statistical capacity-building in developing countries

Source:http://www.icsu.org/publications/reports-and-reviews/review-of-targets-for-the-sustai nable-development-goals-the-science-perspective-2015/sdgs-report-supplement-goals-and-tar gets

\section{Copyright Disclaimer}

Copyright for this article is retained by the author(s), with first publication rights granted to the journal.

This is an open-access article distributed under the terms and conditions of the Creative Commons Attribution license (http://creativecommons.org/licenses/by/3.0/). 